\title{
Root morphology and development of banana and plantain root systems in relation to nematode population
}

\author{
Roger FogAIN ${ }^{a *}$, R. Simon GoWEN ${ }^{b}$
}

${ }^{a}$ Centre Africain de Recherches sur Bananiers et Plantains (CARBAP), BP 832 Douala, Cameroon syngenta.fogain@adsnet.cm

b Department of Agriculture, University of Reading, Earley Gate, PO Box 236, Reading Berks, UK

* Correspondence and reprints

Fruits, 2005, vol. 60, p. 297-302 (C) 2005 Cirad/EDP Sciences All rights reserved DOI: 10.1051/fruits:2005035

RESUMEN EsPAÑoL, p. 302

\section{Root morphology and development of banana and plantain root systems in relation to nematode population.}

Abstract - Introduction. Nematodes are significant pests of bananas and plantains worldwide. Different levels of susceptibility to these pests have been reported. Studies were carried out to investigate differences in root systems and development of Musa clones with different levels of susceptibility and their possible role in the host-parasite relationship. Materials and methods. Five Musa clones, of which four were susceptible and one resistant to the nematode Radopholus similis, were grown in a plot naturally infested by this nematode. Root samples were collected 6 months after planting and measurements were made on the significance of tissue areas in root cross-sections, and the significance of root mass, root development and nematode populations with depth. Results. No significant difference was observed between cultivars in their general structural organisation or the relative significance of the tissue component of the root cross-section. A significantly lower number of air lacunae was found in the resistant accession in comparison with the susceptible ones. All the accessions except Christine (ABB) were comparable in their root development in the soil profile with more than $70 \%$ of the total root mass produced above $40 \mathrm{~cm}$. The greatest nematode population and damage on roots were found at depths between $(20$ and 40$) \mathrm{cm}$. Conclusions. This is the first report on differences in air spaces between Musa cultivars, and their role in the Musa-nematode relationship needs further investigation.

Musa / Cameroon / plant nematodes / host resistance to pests / roots / plant morphology / growth

\section{Morphologie des racines et développement de systèmes racinaires du bananier et du plantain en présence de nématodes.}

Résumé - Introduction. Dans le monde entier, les nématodes sont des parasites importants du bananier et du plantain. Différents niveaux de sensibilité à ces parasites ont été rapportés. Des études ont été effectuées pour étudier les différences existant dans les systèmes racinaires et le développement de clones de Musa présentant différents niveaux de sensibilité et le rôle possible de ces différences dans la relation hôte-parasite. Matériel et méthodes. Cinq clones de Musa, dont quatre sensibles et un résistant au nématode Radopholus similis, ont été plantés dans une parcelle naturellement infestée par ce nématode. Des échantillons de racines ont été prélevés 6 mois après plantation et des mesures ont été faites sur la répartition des différents tissus observés sur des coupes de racine, sur l'importance de la masse de racines, sur leur développement, ainsi que sur les populations de nématodes en fonction de la profondeur du système racinaire. Résultats. Aucune différence significative n'a été observée entre les cultivars ni dans leur organisation structurale générale, ni dans l'importance relative des tissus observés sur les coupes de racine. Le nombre de méats trouvé dans les tissus du clone résistant a été sensiblement inférieur à celui observé chez les clones sensibles. Toutes les accessions autres que Christine (ABB) ont présenté un développement racinaire comparable le long du profil de sol, avec plus de $70 \%$ de la masse totale des racines présents au-dessus de $40 \mathrm{~cm}$. La plus grande population de nématodes et les dommages aux racines les plus sévères ont été trouvés à une profondeur entre (20 et 40$) \mathrm{cm}$. Conclusions. Ces travaux sont les premiers traitant de différences entre méats des tissus racinaires de différents cultivars de Musa ; le rôle qu'ils pourraient jouer dans la relation Musa-nématode devra être étudié par de prochaines recherches.

Musa / Cameroun / nématode des plantes / résistance de l'hôte aux ravageurs / racine / morphologie végétale / croissance 


\section{Introduction}

In contrast with the above-ground parts of plants, very few studies have been done on the below-ground parts [1]. On banana, a little information is available on the underground parts of the plant, but mostly on commercial bananas [2]. These studies are mostly on the description of the root system; only a few of them deal with relationships with pathogens.

The root system plays an important role for a plant. Unfortunately, it is subjected to many attacks by soil pests and diseases, which can cause significant reduction in production. Besides, very few studies have been conducted to investigate the role of the root system as a possible indication of resistance/tolerance or escape mechanisms.

Reports have indicated that intimate relationships do exist between cultivars and pathogens. Biochemical mechanisms have been suspected of being involved in resistance of some $M u s a$ accessions to nematodes $[3,4]$. However, physical differences in development and structure between cultivars have been reported. Lavender et al. [1] found significant differences between clones of Betula pendula in their root systems. They reported differences in root mass and root length, although the latter tends to vary more than the former. Travis et al. [5] reported differences in the anatomy of the stem of two varieties of Brassica namus with different degrees of susceptibility to lodging. They concluded that these differences are probably an indication of varietal performance. According to Berrie et al. [6], variation in the primary structure of roots exists and this is centred on the relative proportion of the cortex and medulla associated

Table I.

Reaction of selected Musa cultivars to Radopholus similis.

\begin{tabular}{lcc}
\hline Cultivars & Subgroup & Reactions \\
\hline Grande Naine & Cavendish, AAA & Susceptible \\
French Sombre & Plantain, AAB & Susceptible \\
Banane Cochon & Lujugira, AAA & Susceptible \\
Christine & Monthan, ABB & Susceptible \\
Yangambi km 5 & Ibota, AAA & Resistant
\end{tabular}

with the number of protoxylem groups and on the presence or absence of air spaces in the cortex.

Root systems of bananas and plantains are made up of root axes and finely branched laterals. The general structure of the main roots has been described by many authors [7, 8].

There is currently no available data on the role of structural anatomy and development of roots of Musa clones in relation to nematode susceptibility or tolerance. This paper discusses the possible contribution of root development and structure to sensitivity of Musa clones to nematodes.

\section{Materials and methods}

Five accessions: French Sombre, Grande Naine, Yangambi km 5, Christine and Banane Cochon, with known levels of susceptibility (table I), were grown in Njombé (Cameroon) on land of volcanic origin naturally infested by the nematode Radopholus similis. Planting material consisted of suckers collected from the CARBAP (Njombé, Cameroon) Musa germplasm collection. Thirtytwo plants were planted for each cultivar. The experimental design was a randomised block design with four replicates of eight plants each. Plants in a replicate were of the same variety. Pits were made 6 months after planting on two plants per replicate (eight plants per accession) to investigate the significance of the root system (root mass and length), nematode populations and damage caused by them on roots in relation to depth.

Two years after planting, roots were collected from only four of the accessions tested: three susceptible and one resistant. Only roots still attached to the mother plants were collected. After washing, hand sections were carried out and the sections were kept in glycerised distilled water for observations. Sections were made up of root pieces cut $10 \mathrm{~cm}$ from the corm. Riopel and Steeves [7] reported that maturation of tissues in the roots is complete (90 to 130) cm from the apex.

The following observations were made:

- Estimation of the thickness of each component of the section using the percent area of the section occupied by each component: 
Table II.

Weights of roots of Musa cultivars taken from the field at different layers of the soil profile up to a depth of $60 \mathrm{~cm}$, and at $50 \mathrm{~cm}$ from the plant (Njombé, Cameroon).

\begin{tabular}{lccccc}
\hline $\begin{array}{l}\text { Depth } \\
\text { (cm) }\end{array}$ & \multicolumn{5}{c}{ Root mass $(\mathrm{g})$} \\
& Grande Naine & French Sombre & Banane Cochon & Yangambi km 5 & Christine \\
\hline $0-10$ & 120.9 & 85.5 & 73.0 & 40.4 & 10.1 \\
$10-20$ & 48.0 & 94.0 & 68.0 & 74.5 & 46.9 \\
$20-30$ & 45.1 & 80.5 & 48.4 & 45.9 & 6.9 \\
$30-40$ & 12.4 & 20.1 & 23.1 & 36.4 & 38.1 \\
$40-50$ & 17.6 & 16.7 & 7.7 & 21.2 & 17.3 \\
$50-60$ & 1.8 & 2.7 & 1.1 & 15.1 & 27.5 \\
\hline Total & 245.8 & 299.5 & 221.3 & 233.5 & 146.8 \\
SED $(n=3)$ & 22.6 & 17.4 & 17.6 & - & - \\
Probability & 0.004 & 0.001 & 0.008 & ns & ns \\
\hline
\end{tabular}

micrometric measurements (linear measurement) were made as described by Quesnel [9]; calculation of the tissue area in the root cross-section was based on the method described by Travis et al. [5].

- Presence or absence of air spaces as well as their abundance was investigated.

- Estimation of nematode populations and root damage: nematodes were extracted from $25 \mathrm{~g}$ of subsamples of roots using the maceration and sieving technique [10]. Root damage was evaluated using a root lesion index based on the area of necrosis on a randomly selected number of root axes [11].

\section{Results and discussion}

\subsection{Root distribution with depth}

In the conditions used in our experiments, the depth of the root system of the cultivars did not exceed (70 to 80 ) $\mathrm{cm}$. This corroborates the report by Blake [12], who found that Cavendish banana roots extend to a depth of $75 \mathrm{~cm}$, and with the works of Irrazary et al. [13], who reported that plantain roots extend no deeper than $45 \mathrm{~cm}$ at five locations in Puerto Rico.

The total root weight and root length collected from different layers of the soil profile showed some differences between cultivars (tables II, III). Most of the cultivars had a similar pattern of root distribution in the soil profile except Christine, which showed a more regular root distribution to a depth of $60 \mathrm{~cm}$. For the cultivars French Sombre, Grande Naine, Banane Cochon and Yangambi $\mathrm{km} 5$, more than $70 \%$ of the roots were found above a depth of $40 \mathrm{~cm}$. Sioussaram [14] and Champion and Sioussaram [15] reported that most of the banana roots develop in the top soil. Godefroy et al. [16] also found that $82 \%$ of roots of East African banana (AAA) were in the horizons close to the soil surface. Total root mass varied between (146.8 and 299.5) g and root length varied between (1060 and 1954) $\mathrm{cm}$ (tables II, III). The cultivar Christine had the lowest root mass and root length and the $\mathrm{cv}$. French Sombre had the highest.

\subsection{Significance of nematodes and damage with depth}

R. similis was extracted from all the samples collected in the soil profile. The distribution of nematode population with depth showed that the cultivar Yangambi $\mathrm{km} 5$ had the lowest population densities at all the depths (table IV). For most of the cultivars, the highest population of nematodes was extracted from root samples collected at depths between (30 and 40) $\mathrm{cm}$. Populations of nematodes from samples collected between (0 and 20) $\mathrm{cm}$ were comparable with those sampled between $(50$ and 70 ) $\mathrm{cm}$. Occasionally, nematode populations greater than $10^{5}$ R. similis $100 \mathrm{~g}^{-1}$ roots were found at greater 
Table III.

Lengths of roots of Musa cultivars taken from the field at different layers of the soil profile up to a depth of $60 \mathrm{~cm}$, and at $50 \mathrm{~cm}$ from the plant (Njombé, Cameroon).

\begin{tabular}{lccccc}
\hline $\begin{array}{l}\text { Depth } \\
(\mathrm{cm})\end{array}$ & Grande Naine & French Sombre & Banane Cochon & Yangambi km 5 & Christine \\
\hline $0-10$ & 964 & 549 & 613 & 363 & 119 \\
$10-20$ & 312 & 392 & 615 & 661 & 323 \\
$20-30$ & 252 & 338 & 325 & 290 & 81 \\
$30-40$ & 80 & 227 & 172 & 353 & 185 \\
$40-50$ & 83 & 143 & 54 & 172 & 139 \\
$50-60$ & 14 & 31 & 11 & 115 & 213 \\
\hline Total & 1705 & 1680 & 1790 & 1954 & 1060 \\
SED $(n=3)$ & 214 & 123 & 126 & - & - \\
Probability & 0.012 & 0.021 & 0.002 & ns & ns
\end{tabular}

\section{Table IV.}

Population densities of Radopholus similis in roots of different Musa cultivars at different layers of the soil profile up to a depth of $60 \mathrm{~cm}$, and at $50 \mathrm{~cm}$ from the plant (Njombé, Cameroon).

\begin{tabular}{lccccc}
\hline $\begin{array}{l}\text { Depth } \\
(\mathrm{cm})\end{array}$ & Grande Naine & French Sombre & Banane Cochon & Yangambi km 5 & Christine \\
\hline $0-10$ & 64.0 & 43.8 & 76 & 1.4 & 27.4 \\
$10-20$ & 86.0 & 57.0 & 56 & 8.0 & 82.8 \\
$20-30$ & 102.0 & 141.0 & 133 & 1.2 & 52.4 \\
$30-40$ & 101.0 & 36.0 & 213 & 2.0 & 139.0 \\
$40-50$ & 150.0 & 50.0 & 117 & 2.8 & 41.0 \\
$50-60$ & - & - & - & 6 & 3.6 \\
\hline
\end{tabular}

depth. Even the resistant cultivar Yangambi $\mathrm{km} 5$ has the greatest part of its root system in the horizon where $R$. similis was abundant. Damage on roots caused by R. similis was observed at different horizons in the soil profile (table V). It is important to note that severe root damage was also observed at greater depth.

\subsection{Thickness of tissue areas}

The percent area of the cross-section occupied by the cortex varied between $(57.4$ and 63.2)\%. The cultivar Grande Naine had the thinnest cortex while Yangambi km 5, French Sombre and Christine were comparable in their thickness. Although a significant difference was found between cultivars in the thickness of the cortex, no relation seems to exist between the thickness of cortical tissue and the susceptibility levels, since Yangambi km 5 was comparable with susceptible cultivars (table VI). In all cases, the cortical zone showed three major areas, as reported by Riopel and Steeves [7]: the outer region with medium size cells, the inner region with small cells and the intermediate region with large cells. Air spaces or air lacunae are found in the third region.

The tissue area occupied by the stele in the total root cross-section varied between (37.5 and 40.6)\%. Although the cultivar 
Table V.

Root lesion index of different Musa cultivars at different layers of the soil profile up to a depth of $60 \mathrm{~cm}$, and at $50 \mathrm{~cm}$ from the plant, 6 months after planting (Njombé, Cameroon).

\begin{tabular}{lccccc}
\hline $\begin{array}{l}\text { Depth } \\
(\mathrm{cm})\end{array}$ & Grande Naine & French Sombre & Banane Cochon & Yangambi km 5 & Christine \\
\hline $0-10$ & 4.3 & 6.4 & 5.1 & 3.3 & 2.8 \\
$10-20$ & 6.5 & 6.9 & 5.0 & 3.4 & 5.8 \\
$20-30$ & 6.3 & 7.2 & 7.5 & 3.8 & 3.6 \\
$30-40$ & 4.6 & 6.4 & 5.4 & 0.6 & 6.8 \\
$40-50$ & 4.7 & 4.8 & 2.9 & 1.9 & 3.2 \\
50-60 & - & - & - & 1.0 & 2.6 \\
\hline SED $(n=3)$ & - & 1.2 & - & - & - \\
Probability & ns & 0.01 & ns & ns & ns \\
\hline -: no observation made. & & & & &
\end{tabular}

Christine showed the greatest stele size, the difference was not significant (table VI).

\subsection{Presence or absence of air spaces}

The number of air spaces was counted under the microscope and significant differences were observed between cultivars (table VI). There were significantly fewer air lacunae in Yangambi $\mathrm{km} 5$ than in the other cultivars. This result indicates that susceptible cultivars show the highest number of air spaces. Berrie et al. [6] reported that the presence or absence of air spaces in the cortex is one of the criteria of variation in the primary root structure.

\section{Conclusions}

Our study shows that $R$. similis causes damage on banana and plantain roots at every depth. However, the greatest nematode population densities and damage are found at depths between (20 and 40) cm. This depth also corresponds to the soil horizon where the largest amount of roots of most of the Musa cultivars are found. These results indicate that tolerance of Musa cultivars cannot be attributed to the root system developing at greater depth and, therefore, escaping nematode damage, since susceptible as well as resistant cultivars showed more than $70 \%$
Table VI.

Comparison of relative areas of cortex and stele in root axes of four Musa cultivars (Njombé, Cameroon).

\begin{tabular}{lccc} 
Cultivars & $\begin{array}{c}\text { Cortex area } \\
(\%)\end{array}$ & $\begin{array}{c}\text { Stele area } \\
(\%)\end{array}$ & $\begin{array}{c}\text { Number } \\
\text { of air spaces }\end{array}$ \\
\hline French Sombre & 61.5 & 37.5 & 41 \\
Grande Naine & 60.1 & 37.6 & 33 \\
Christine & 57.4 & 40.6 & 45 \\
Yangambi km 5 & 63.2 & 35.7 & 13 \\
SED $(n=3)$ & 2.0 & 3.0 & 3.4 \\
Probability & 0.01 & ns & 0.001
\end{tabular}

of their total roots in the first $40 \mathrm{~cm}$ of the soil profile.

It was found that all the cultivars have a similar primary spatial organisation of the root structure. Differences were observed in the areas occupied by different components of the tissues but the difference was not related to the susceptibility level of the cultivars to $R$. similis. The major difference found was in the number of air spaces in the cortical parenchyma. This number was lower in Yangambi km 5 than in susceptible cultivars. Whether this lower number of air lacunae in Yangambi $\mathrm{km} 5$ has any effect on the host-pathogen interaction needs further investigation. Further experiments are needed to understand the role of air spaces in susceptibility to $R$. similis. 


\section{References}

[1] Lavender E.A., Atkinso D., Mackie-Dawson L.A., Variation in root development in genotypes of Betula pendula, Asp. Appl. Biol. 34 (1993) 183-192.

[2] Price N.S., Banana morphology. Part 1: Root and rhizome, in: Gowen S. (Ed.), Bananas and plantains, Chapman \& Hall, London, UK, 1995, pp. 179-189.

[3] Mateille T., Comparative host tissue reactions of Musa acuminata (AAA group) cvs Poyo and Gros Michel to three banana parasitic nematodes, Ann. Appl. Biol. 124 (1) (1994) 65-73.

[4] Fogain R., Gowen S.R., Investigations on possible mechanisms of resistance to nematodes in Musa, Euphytica 92 (3) (1996) 375-381.

[5] Travis A.J., Murison S.D., Chesson A., Walker K.C., Quantitative measurement of stem anatomy as an indicator of varietal performance, Asp. Appl. Biol. 34 (1993) 335-343.

[6] Berrie G.K., Berrie A., Eze J.M.O., Root structure and function, in: Tropical Plant Science, Longman, Harlow, UK, 1987.

[7] Riopel J.L., Steeves T.A., Studies on the roots of Musa acuminata cv. Gros Michel. 1. The anatomy and development of main roots, Ann. Bot. 28 (1964) 475-490.

[8] Kwa M., Architecture, morphogenèse et anatomie de quelques cultivars de bananiers, Univ. Montpellier II, thèse, Montpellier, France, 1993.

[9] Quesnel L.B., Microscopy and micrometry, in: Noms I.R., Ribbons D.W. (Eds.), Methods in microbiology, Vol. 5A, Acad. Press, London, UK, 1971, pp. 1-104.
[10] Southey J.F., Principles of sampling for nematodes, in: Southey J.F. (Ed.), Laboratory methods for work with plant and soil nematodes, HMSO Books, Norfolk, UK, 1986, pp. 1-4.

[11] Bridge J., Gowen S.R., Visual assessment of plant parasitic nematodes and weevil damage on banana and plantain, in: Gold C.S., Gemill B. (Eds), Biological and integrated control of Highland banana and plantain pests and diseases, Proc. Res. Coord. Meet., Cotonou, Benin, 12-14 Nov. 1991, IITA, Ibadan, Nigeria, 1993, pp. 147-154.

[12] Blake C.D., Nematode parasites of bananas and their control, in: Peachey E.J. (Ed.), Nematodes of tropical crops, Tech. Commun. No. 40, Commonw. Inst. Helminthol., Commonw. Agric. Bur., Farnham Royal, UK, 1969, pp. 109-132.

[13] Irrizary H., Vicente-Chandler J., Silva S., Root distribution of plantains growing on five soil types, J. Agric. Univ. Puerto Rico 65 (1981) 29-34.

[14] Sioussaram D., Observations préliminaires sur l'enracinement des bananiers dans les sols de la station de Neufchateau, Guadeloupe, Fruits 23 (9) (1968) 847-859.

[15] Champion J., Sioussaram D., L'enracinement du bananier dans les conditions de la station de Neufchateau (Guadeloupe), Fruits 25 (12) (1970) 847-859.

[16] Godefroy J., Lassoudière A., Rutunga V., Sebahutu A., Caractéristiques des parties aériennes et du système racinaire des bananiers triploïdes ' $A A A^{\prime}$ ', sous-groupe bananes à bière de l'Afrique de l'Est, cultivées au Rwanda, Fruits 47 (2) (1992) 277-280.

\section{Morfología de las raíces y desarrollo de sistemas de raíz de los bananos y de} los llantenes menores en presencia de nematodos.

Resumen - Introducción. En todo el mundo, los nematodos son parásitos importantes de los bananos y de los llantenes menores. Se informaron distintos niveles de sensibilidad ante estos parásitos. Se llevaron a cabo estudios para estudiar las diferencias existentes entre los sistemas de raíz y el desarrollo de clones de Musa que presentaban distintos niveles de sensibilidad y la función eventual de estas diferencias en la relación huésped-parásito. Material y métodos. Se plantaron en una parcela naturalmente infestada por este nematodo cinco clones de $M u s a$, de los cuales cuatro eran sensibles y uno resistente al nematodo Radopholus similis. Se tomaron algunas muestras de raíces 6 meses después de plantación y se hicieron algunas medidas de la distribución de los distintos tejidos observados sobre cortes de la raíz, de la importancia de la masa de raíces, de sus desarrollos, así como de las poblaciones de nematodos en función de la profundidad del sistema de raíz. Resultados. Ninguna diferencia significativa se observó entre los cultivares ni en su organización estructural general, ni en la importancia relativa de los tejidos observados sobre los cortes de raíz. El número de meatos encontrados en los tejidos del clon resistente fue sensiblemente inferior al que se observó en los clones sensibles. Todos los clones salvo Christine (ABB) presentaron un desarrollo de raíz comparable a lo largo del perfil de suelo, con más de un 70\% de la masa total de las raíces presentes por encima de $40 \mathrm{~cm}$. Se encontró la población más grande de nematodo y los daños de las raíces más severas a una profundidad de entre $(20$ y 40$) \mathrm{cm}$. Conclusión. Estos trabajos son los primeros que tratan de las diferencias entre meatos en tejidos de raíz de los distintos cultivares de $M u s a$; el papel que podrían desempeñar en la relación $M u s a$-nematodo deberá estudiarse en futuras investigaciones.

Musa / Camerún / nematodos de las plantas / resistencia del huésped a plagas / raices / morfología vegetal / crecimiento 